\title{
The Corrective Tax Versus Liability As Solutions to the Problem of Harmful Externalities
}

\section{Citation}

Steven Shavell, The Corrective Tax versus Liability As Solutions to the Problem of Harmful Externalities (Harvard John M. Olin Center for Law, Economics and Business, Discussion Paper No. 672, 2010)

\section{Permanent link}

http://nrs.harvard.edu/urn-3:HUL.InstRepos:4322593

\section{Terms of Use}

This article was downloaded from Harvard University's DASH repository, and is made available under the terms and conditions applicable to Other Posted Material, as set forth at http:// nrs.harvard.edu/urn-3:HUL.InstRepos:dash.current.terms-of-use\#LAA

\section{Share Your Story}

The Harvard community has made this article openly available.

Please share how this access benefits you. Submit a story.

Accessibility 


\title{
HARVARD
}

JOHN M. OLIN CENTER FOR LAW, ECONOMICS, AND BUSINESS

\author{
THE CORRECTIVE TAX VERSUS LIABILITY \\ AS SOLUTIONS TO THE PROBLEM OF \\ HARMFUL EXTERNALITIES
}

\author{
Steven Shavell \\ Discussion Paper No. 672 \\ $07 / 2010$ \\ Harvard Law School \\ Cambridge, MA 02138
}

This paper can be downloaded without charge from:

The Harvard John M. Olin Discussion Paper Series: http://www.law.harvard.edu/programs/olin_center/

The Social Science Research Network Electronic Paper Collection: http://ssrn.com/ 
forthcoming, Journal of Law and Economics

\title{
The Corrective Tax versus Liability
}

\section{As Solutions to the Problem of Harmful Externalities}

\author{
Steven Shavell*
}

Although the corrective tax has long been viewed by economists as a theoretically desirable remedy for the problem of harmful externalities, its actual use has been limited, mainly to the domain of pollution. Liability, in contrast, has great importance in controlling harmful externalities. I compare the tax and liability here in theory and suggest that the conclusions help to explain the observed predominance of liability over taxation, except in the area of pollution. The following factors are emphasized in the analysis: inefficiency of incentives under taxes when, as would be typical, it would be impractical for the state to incorporate into taxes all of the variables that significantly affect expected harm; efficiency of incentives under strict liability, which requires only that actual harms be measured; efficiency of incentives to exercise precautions under the negligence rule; administrative cost advantages of liability deriving from its being applied only when harm occurs; and dilution of incentives under liability when suit would be unlikely or injurers would not be able to pay fully for harms caused.

* Samuel R. Rosenthal Professor of Law and Economics, Harvard Law School. I thank Richard Epstein, Louis Kaplow, A. Mitchell Polinsky, Richard Posner, and Rob Stavins for comments and the John M. Olin Center for Law, Economics, and Business at Harvard Law School for research support on this article. 


\section{The Corrective Tax versus Liability As Solutions to the Problem of Harmful Externalities}

\section{Introduction}

The corrective tax has long been viewed by most economists as a, or the, theoretically preferred remedy for the problem of harmful externalities. Since the writing of Pigou, the imposition of a tax equal to the expected harm that an activity generates has been taken to be a desirable instrument for the control of harm because the bearing of such a tax should lead parties to moderate harm in a socially efficient manner. ${ }^{1}$

Textbooks, surveys of the externality literature, and the oral tradition of the economics profession all reflect this general understanding. ${ }^{2}$

When, however, the actual employment of corrective taxes is considered, one sees that it is restricted. The primary area of application of corrective taxes concerns pollution, such as that due to carbon and sulfur dioxides and industrial water emissions, but even here their use is limited. ${ }^{3}$ Taxes on certain non-polluting activities may also have corrective elements; the tax on alcohol, for instance, may serve not only as a means

\footnotetext{
${ }^{1}$ Pigou (1932, pp. 172-203). Pigou first articulated the generality of the problem of externalities and the possible need for government intervention, including taxation (pp. 192-96), as a solution.

${ }^{2}$ For examples from textbooks of the argument that taxes are desirable as a cure for externalities, see Mankiw (2009, pp. 210-14), Pindyck and Rubinfeld (2009, pp. 651-60), and Mas-Colell, Whinston, and Green (1995, pp. 354-56); for examples from surveys of the externality literature, see Bovenberg and Goulder (2002, pp. 1477-90) and Helfand, Berck, and Maull (2003). Although the tax is viewed as a good solution to externality problems, informational difficulties in its implementation and the possibility that regulation could sometimes be superior are given increasing attention in the literature, on which see note 8 below.

${ }^{3}$ See Stavins (2003) for a review of the use of corrective taxes to control pollution and other environmental externalities. From this review, it appears that taxes are used little, if at all, to control pollution in the United States (Table 1, pp. 364-68, lists no use of effluent fees in this country). However, as Stavins documents, certain fees may be partially motivated by a desire to reduce pollution, for example, charges for purchase of non-refillable containers and payments for aircraft landings and takeoffs. Also, market-based policies that share features with corrective taxes, notably subsidies and tradeable permit systems, are employed to ameliorate environmental externalities.
} 
of raising revenue but as well as a way of staunching the social costs of alcoholism.

Apart from a number of examples like these, though, it is difficult to adduce instances of the use of corrective taxes.

Thus, it is evident that the territory of the corrective tax covers only a tiny fraction of the total terrain of personal and business activities that can cause harm to others, from driving a car, to cooking with a barbecue, to transporting oil, to using a crane in construction. The list of activities for which problems of harm are not addressed by corrective taxes is practically endless.

The typical ways that government does intervene to control harmful activities are through policies apart from corrective taxes, and notably through regulation and the imposition of liability on injurers for harms that they cause. ${ }^{4}$ In this article, I consider liability as an alternative to taxation. My objective is to achieve an understanding of the relative merits of liability and of taxation in theory, and to see if this understanding sheds light on the observed dominance of liability over taxation as a means of controlling harmful activities. $^{5}$

I begin in Section 2 with a discussion of the advantages and disadvantages of corrective taxation. The standard advantage of taxation is, as noted, that it can in theory lead to socially desirable control of harmful activities: if a party who is engaged in a harmful activity has to pay a tax equal to the expected harm that it causes, the party should be induced to efficiently reduce the expected harm.

\footnotetext{
${ }^{4}$ The injunction and criminal sanctions are other important instruments of control.

${ }^{5}$ That the scope of use of liability is great is evident from, for example, references on tort law, such as Dobbs (2000), whereas the use of corrective taxes, even under the broadest definition, is miniscule by comparison.
} 
Implementing taxation would often be problematic, however. A major difficulty is that the expected harm would frequently be difficult for the tax authority to estimate because it usually depends on a multiplicity of variables. The expected harm associated with the use of a crane, for example, would be hard to gauge because it would depend on the size of the crane, the nature of the crane's loads, the care exercised by the crane's operators, the number of passersby exposed to risk from crane accidents, and so forth. For this reason, I assume for the most part that taxes would be incomplete - that taxes would be an explicit function of only a subset of the variables that determine the expected harm.

Taxes would suffer from two problems on account of their incompleteness. ${ }^{6}$ First, they would often be inaccurate (for instance, too high if the number of passersby exposed to risk from cranes is less than average, too low if the number of passersby is greater than average), leading to inefficiency. Second, taxes would result in creation of excessive risk to the extent that dimensions of care and other untaxed variables are under the control of taxed parties (if care in the use of cranes is not taxed, there will be no taxrelated incentives to take such care).

A third factor reducing the desirability of taxation is the administrative costs of their use, especially in contexts where the number of occasions in which the tax would have to be imposed is great.

I suggest that these drawbacks of taxation would be significant for most harmful activities, but not for activities that generate certain important types of pollution. In the domain of pollution, the problems of measuring the expected harm appear often to be of a (2011).

${ }^{6}$ The two problems to be described are studied in a model of taxation versus liability in Shavell 
relatively low order, administrative costs may not be high, and the ability to utilize taxation may thus be reasonably good

In Section 3, I consider strict liability, one of the two major forms of liability, and I compare strict liability to corrective taxation. Under strict liability, an injurer is supposed to pay for the harm caused to a victim. The classic argument in favor of strict liability is that it should lead to socially desirable control of harmful activities: if a party who undertakes a harmful activity is required to pay for the actual harm that occurs, the party should be properly induced to lower the expected harm. However, for strict liability to influence injuring parties optimally, they must always be sued and have to pay for the harm they do. If parties who cause harm might not be sued - because harm cannot be attributed to them or because it is too dispersed to make suit financially worthwhile - or if they lack the assets to pay fully for the harm, the incentive inherent in the threat of liability will be diluted.

Strict liability possesses several advantages over taxation, and taxation holds an advantage over strict liability. To impose strict liability and create desirable incentives, the state need only measure the harms that occur (losses caused by actual crane accidents), implying that the problems due to incompleteness of taxes are avoided; there is no inefficiency due to inaccuracy of taxes and no problem of excessive risk due to lack of tax-associated incentives to take care. Another advantage of strict liability concerns administrative costs. Unlike taxation, strict liability applies only when harm occurs, meaning that liability may result in administrative costs savings to the extent that the probability of harm is low, as it often is. On the other hand, taxation enjoys an advantage over liability because the factors that reduce the effectiveness of liability (the possibility 
that suit would not be brought and inability to pay for the harm that occurs) do not usually lower the effectiveness of the tax.

This comparison of strict liability to taxation appears to favor liability for most harmful activities. However, it seems that the comparison favors taxation in the area of general pollution, especially because the likelihood that suits would be brought for pollution-caused harm or that full damages would be paid for it is not high, compromising the effectiveness of liability.

In Section 4, I examine liability based on the negligence rule, the other major form of liability. Under the negligence rule, an injurer is obligated to pay for the harm caused to a victim only if the injurer's behavior fell below a legal standard of appropriate care. The virtue of the negligence rule is that it can induce injurers to exercise efficient care (safely secure loads to cranes). But it does not lead injurers to moderate their levels of harmful activity (the number of times cranes are used), for the level of activity is ordinarily not part of the negligence determination. In any event, for the negligence rule to affect injurers' behavior, they must expect to be sued for negligence and to pay for harm; otherwise their incentives to take appropriate care will be reduced.

It follows that the negligence rule is superior to the tax in controlling dimensions of care, is inferior to the tax in controlling the level of harmful activities, enjoys a possible administrative cost advantage over the tax owing to the ex post nature of liability, and suffers from the disadvantage that its effectiveness is lowered by the general factors that dilute expected liability.

In Section 5, I address the issue of the optimal rule of liability - the choice between strict liability and negligence. The relevance of the choice for the comparison of 
taxation to liability is that the comparison of taxation should be made to the optimal rule of liability, not just to strict liability or just to the negligence rule. This consideration reinforces my conjecture that liability is superior to the tax for controlling most harmful activities.

In Section 6, I consider the use of taxation in combination with liability. That is, I ask how these policies might complement each other, and also how they might work at cross purposes, principally because imposition of both taxation and liability could result in payments by injurers that exceed the expected harm that they generate.

Before proceeding, let me note that my topic lies within the intellectual agenda set out by Ronald Coase fifty years ago in his important article, "The Problem of Social Costs,"7 and thus seems fitting for inclusion in this issue of the Journal of Law and Econmics published in celebration of his long scholarly career. Coase criticized Pigou in his article, mainly because Coase questioned the presumption that government intervention is usually needed to correct externality problems; he emphasized that the concerned parties might well be able to bargain toward a resolution of their problems. The issues raised here about Pigouvian taxation are different from those examined by Coase, of course, as they concern not whether government intervention is needed to correct externalities but rather its optimal character if it is. What is said below relates also to economics literature on informational difficulties that arise in applying corrective taxation, ${ }^{8}$ although the economics literature essentially ignores liability as an alternative

\footnotetext{
${ }^{7}$ Coase (1960).

${ }^{8}$ See, for example, Adar and Griffin (1976), Baumol and Oates (1988), Bovenberg and Goulder (2002, pp. 1524-30), Kaplow and Shavell (2002), and especially Weitzman (1974). This literature focuses on variation among parties in the costs of controlling pollution and uncertainty in the harm it causes, and compares taxation to regulation. Here I focus on variation among parties in the expected harm caused by
} 
to taxation. ${ }^{9}$ What is said relates as well to law and economics literature comparing different policies for the control of harmful externalities. ${ }^{10}$

\section{The Corrective Tax}

In order to evaluate the virtues and demerits of the corrective tax, one must, of course, define it. I said above that it equals the expected harm - the probabilitydiscounted harm - not the actual harm. The definition of the tax as the expected harm is consistent with most economic literature concerned with taxes and uncertain harm ${ }^{11}$ and is in keeping with the notion of the tax as an amount collected at the time that parties engage in potentially harmful activities. Were the tax conceived to be an amount collected ex post, equal to the actual harm rather than the expected harm, then, for example, in the context of pollution, calculation of the tax would require the state to identify how much disease was in fact caused by a pollutant, how many animals died due

their activities and the difficulties associated with untaxed variables that affect the expected harm, and I compare taxation to liability.

${ }^{9}$ For example, Mankiw (2009, pp. 210-19) and Mas-Colell, Whinston, and Green (1995, pp. 35459) make no mention of liability, and Bovenberg and Goulder (2002, pp. 1527-28) and Pindyck and Rubinfeld (2009, pp. 671-72) note liability only briefly; all of these references treat regulation as a major alternative to taxation. I am aware of no article in the economics literature that examines liability as a substitute for taxation. The lack of attention given to liability in the economics literature is unfortunate given its relevance to the control of harmful externalities. Even in the domain of pollution, to which the economics literature on externalities devotes its main attention, liability plays an important role; see, for instance, Farber, Freeman, Carlson, and Findley (2006, pp. 154-68, 841-925).

${ }^{10}$ See Shavell (1993), noting the possible administrative advantages of liability over the tax in that liability applies only if harm occurs, and the weaknesses of liability in that liability requires that suit be brought and that parties have assets sufficient to pay for harm; and White and Wittman (1983), emphasizing the advantages of strict liability over the tax due to informational problems in applying the latter. See also the remarks of Posner (2007, pp. 396-400) about pollution, stressing informational difficulties of implementing pollution taxes and the weaknesses of liability.

${ }^{11} \mathrm{See}$, for example, the sources in note 8 . In no case, to my knowledge, is the tax assumed to be the actual harm in a model with uncertain harm. Instead the tax is taken to be the expected harm or else (and more commonly) a linear function of a single taxed variable, notably the level of a pollutant, which equals the expected harm at a particular level of emissions. 
to exposure to it, how much paint prematurely peeled on account of it, and so forth. ${ }^{12}$

Instead, I presume the corrective tax to be an amount collected ex ante and based on a statistical estimate of the harm that would come about due to the emission of a pollutant or whatever is the harmful activity at issue.

The standard argument regarding the efficiency of the corrective tax is, as was noted, that when an injurer makes any decision, the injurer will take into account its influence on the tax and thus on expected harm; consequently, the injurer's decisions will be socially appropriate. ${ }^{13}$ A polluter will therefore increase its level of production and its accompanying discharges of pollutants if and only if the extra profits that result exceed the expected harm from the pollutants; or if a polluter contemplates purchasing a device to abate the discharges, it will do so if and only if the cost of the device is less than the expected harm avoided.

There are, however, a number of problems that would arise in employing corrective taxes. To appreciate the character of these problems, it will be useful for me first to list several examples of activities and to identify for each variables that are important determinants of the expected harm.

Polluting activities. The expected harm from some forms of pollution is a function mainly of the quantity of the pollutant released by the polluter. In the stock example of pollution, this characteristic of pollutants is assumed, and it might be thought to apply in fact in contexts where pollutants spread over large areas and their ambient

\footnotetext{
${ }^{12}$ Likewise, were the corrective tax on alcohol defined to be the actual harm due to its consumption, the various problems flowing from that consumption - such as accidents caused by drunk driving, domestic violence, and difficulties at the workplace - would all have to be traced and properly evaluated.

${ }^{13}$ I will often call the party engaged in a potentially harmful activity the injurer even though this party may not turn out actually to cause harm.
} 
level is the chief determinant of expected harm. Pollution that fits this description is typically the aggregated result of discharges from many sources, and I will refer to such pollution as general pollution. ${ }^{14}$

However, pollution may be of a type such that the expected harm depends importantly not just on the quantity of the pollutant that is discharged by a polluter, but also on additional variables particular to the polluter. Suppose that the pollutant is a chemical that will cause harm primarily in a circumscribed area surrounding the polluter if the chemical infiltrates a person's water supply. Then the expected harm would depend not just on the amount of the chemical that is discharged by the polluter, but also on the number of individuals living within the zone of danger determined by the polluter's location and whether these individuals draw their water from wells (that could be contaminated by the chemical) or obtain it through pipes (that could not). I will sometimes refer to pollution of this type as localized pollution.

Operation of cranes. As I indicated above, the expected harm caused by the use of a crane is influenced by factors including the type of the crane (height, weight, tensile strength of lifting cables), the nature of the objects it lifts, the intensity of its use, the care with which it is operated, and the exposure of victims to risk (the number of people vulnerable to injury were the crane to topple or to drop an object).

Driving cars. Here the expected harm from accidents depends on miles driven, care exercised in driving (speed, use of turn signals), vehicle condition and maintenance (affecting the operation of lights, brakes, horn), type and weight of vehicle,

\footnotetext{
${ }^{14}$ Examples are pollution that leads to depletion of the ozone layer in the atmosphere or pollution that contributes to global warming.
} 
characteristics of roads on which driving is done (number of lanes, visibility, traffic density), and so forth. ${ }^{15}$

Clearing ice and snow from sidewalks. The expected harm from ice and snow left on a sidewalk is affected by, among other things, its quantity, the time it takes to melt, its slipperiness, steps taken to reduce its slipperiness (use of salt, sawdust, wood planks), and the foot traffic on the sidewalk.

These examples illustrate the point that the variables which are relevant to the determination of the expected harm from an activity are usually numerous; the case of general pollution, for which the expected harm is a function mainly of a single variable, the quantity of emissions, is not typical. Hence, it would frequently be difficult or impractical for the state to employ a tax that depends on all of the variables that bear in a real way on the expected harm.

Therefore, I now assume that a tax would be incomplete: it would be an explicit function of only a subset of the variables that determine the expected harm. However, I assume that the taxed variables would include a variable called the level of activity, such as the number of construction sites at which a crane is used, the number of miles driven in a car, or the amount of snow left on a sidewalk. Both taxed and untaxed variables might be chosen by parties or be otherwise determined. ${ }^{16}$

The presence of untaxed variables that influence the expected harm would lead to two types of problem. First, taxes would often be inaccurate, unequal to the expected

\footnotetext{
${ }^{15}$ In discussing the example of driving, I will be considering harm due to accidents, not harm due to pollution from the use of gasoline.

${ }^{16}$ To amplify, let $x$ be the vector of taxed variables, $y$ the vector of untaxed variables, and $h(x, y)$ the expected harm given $x$ and $y$. The tax $t(x)$ is assumed to equal the expected harm given $x$. I will use this notation in later footnotes.
} 
harm. The tax on crane operations would often be inaccurate if it were not based on the loads that a crane lifts and the exposure of victims to risk; the tax on driving would often be biased if it did not reflect the care and skill of drivers and the types of roads on which driving is done; the tax on snow and ice left on sidewalks would often be erroneous if it did not depend on the slipperiness of the snow, how long it takes to melt, and the amount of foot traffic on the sidewalks. Hence, the tax would sometimes be too high, such as when a crane lifts lighter than average loads and few individuals are exposed to risk at a construction site, when ice and snow quickly melts and there is little foot traffic on the sidewalks, or when drivers are careful and drive new cars mainly on well-designed, limited access roads. And sometimes the tax would be too low, such as when an older crane lifts heavy loads and many individuals are exposed to risk, or when ice and snow will remain for a long period where foot traffic is high, and so forth.

The general consequence of inaccurate taxes is that parties would choose taxed variables inappropriately. Parties for whom the tax exceeds the expected harm would engage too little in their activities and parties for whom the tax is less than the expected harm would engage excessively in their activities. Drivers and crane operators for whom the tax is too high would drive too little and use cranes too little; and conversely for drivers and crane operators for whom the tax is too low. ${ }^{17}$ Not just the level of activity

\footnotetext{
${ }^{17}$ To illustrate, suppose that $x$ is the level of activity, $y$ is an exogenous parameter (such as an index of the number of potential victims of harm) that varies across the population of injurers, and $h(x, y)=$ $x y$, so that $y$ is the expected harm per unit of activity. Suppose also that the utility or benefit of an injurer is $b(x)$, which is increasing and concave in $x$. Then, under a utilitarian social welfare function, the socially best $x$ maximizes $b(x)-x y$; this best $x$ (which I assume to be positive) is determined by $b^{\prime}(x)=y$ and will be denoted by $x^{*}(y)$, which can be verified to be increasing in $y$. The tax $t(x)$ is assumed to equal $x \mathrm{E}(y)$, where $\mathrm{E}(y)$ is the expected value of $y$. Hence, all injurers will choose $x$ determined by $b^{\prime}(x)=\mathrm{E}(y)$, so all will choose $x^{*}(\mathrm{E}(y))$. Hence, those injurers for whom $y<\mathrm{E}(y)$ choose too high an $x$-because for them, $x^{*}(\mathrm{E}(y))>x^{*}(y)$; and those injurers for whom $y>\mathrm{E}(y)$ choose too low an $x$-because for them, $x^{*}(\mathrm{E}(y))<$ $x^{*}(y)$. For elaboration, see Shavell (2011).
} 
but also other taxed variables would be distorted by inaccurate taxes. For example, if the tax on driving depends on vehicle maintenance, then too much would be invested in vehicle maintenance if the tax is too high, and too little if the tax is too low.

The second problem associated with the presence of untaxed variables is that parties would choose these untaxed variables without regard to their effect on expected harm, implying that expected harm would tend to be socially excessive. Suppose that taxes on crane operators and on drivers do not depend on their degree of care, or that taxes on snow and ice do not depend on whether salting or other steps are taken to reduce its slipperiness. Then the care exercised in the use of cranes and of cars would be too low and too little would be done to reduce the slipperiness of snow and ice because individuals would receive no reduction in their taxes for lowering expected harm in these ways. In other words, there would be an overall tendency for expected harm to be inefficiently high to the extent that untaxed variables are under the control of injurers. It should be noted that this point is different from that discussed in the previous paragraph concerning inaccuracy of taxes and the choice made about taxed variables; the problem here has no necessary connection to inaccuracy of taxes. ${ }^{18}$

${ }^{18}$ Suppose as in the preceding note that $h(x, y)=x y$, but assume here for simplicity that $y$ is the same for all individuals. Assume also that $y$ is given by $y(e)$, where $e$ is an individual's level of care and $y$ is decreasing and convex in $e$. Assume further that the individual exercises $e$ each time he engages in his activity and thus that his utility is $b(x)-x e$. Then the socially best $x$ and $e$ maximize $b(x)-x e-x y(e))=$ $b(x)-x(e+y(e))$. Hence, the optimal $y$ and $e$ (which I assume to be positive) are determined by $b^{\prime}(x)=e+$ $y(e)$, and $y^{\prime}(e)=-1$; these optimal values will be denoted by $x^{*}$ and $e^{*}$. Note that $e^{*}$ minimizes $e+y(e)$. The individual will choose $x$ and $e$ to maximize $b(x)-t(x)-x e$, so that he will choose $e=0<e^{*}$. That is, he has no reason to exercise costly care to lower $y$ since the tax depends only on his level of activity $x$. Because the tax $t(x)$ equals $x \mathrm{E}(y)$, it reduces to $x y(0)$. Therefore, the individual will choose $x$ to maximize $b(x)-x y(0)$, and $x$ will be determined by $b^{\prime}(x)=y(0)$. This can be shown to imply that $x<x^{*}$ (because $y(0)$ $\left.>e^{*}+y\left(e^{*}\right)\right)$. In other words, the untaxed variable $y$ will be chosen so that expected harm per unit of activity is excessive and the level of activity is suboptimal, although it is optimal given the suboptimal $y$. Also, observe that the tax is not inaccurate - it equals the actual expected harm that all (identical) individuals generate; the inefficiency is due to the fact that there is no incentive to improve the level of the untaxed variable $y$ through the exercise of care $e$. Again, for elaboration, see Shavell (2011). 
Another problem associated with taxation concerns the administrative costs of its use. To apply corrective taxes, three tasks must be undertaken, each of which involves expense. First, the state must ascertain the functional relationship between taxed variables and expected harm. Because this functional relationship would be likely to depend on multiple variables, its determination would not be simple. Second, the state must observe the taxed variables. In many contexts, the costs of observation would be significant or even prohibitive. If the amount of snow and ice left on sidewalks were taxed, measurements would have to be made at virtually all property after each snowfall. If steps taken to reduce the slipperiness of snow and ice were a taxed variable, or if the care exercised in driving a car or in operating a crane were a taxed variable, then the amount of monitoring required of tax authorities would be truly great. Third, the state must collect the tax, which would often involve non-negligible expense.

In describing these administrative costs, I have largely taken the identity of the taxed variables as given, but the selection of the set of taxed variables is obviously an economic decision. A variable will be desirable to tax if the benefit of so doing, derived from improved incentives to reduce harm, exceeds the administrative costs of adding the variable to the other taxed variables. In considering taxes, then, we should be thinking of taxes that incorporate the optimal set of taxed variables.

Now that I have described the various problems associated with the corrective tax - inefficiency due to inaccuracy, excessive risk, and administrative costs - let me summarize by commenting on their likely significance for activities producing general pollution versus for most other activities. 
It seems that taxes can perform tolerably well in moderating harm from general pollution. In this setting, the expected harm depends mainly on a single variable, the quantity of emissions, so that a tax could provide a good estimate of expected harm and lead to approximately desirable behavior of taxed parties; problems of inefficiency and of excessive risk due to the presence of untaxed variables would be largely moot. As long as the measurement and the collection of taxes would not be difficult, therefore, the tax could function reasonably well to control general pollution. ${ }^{19}$

However, for most harmful activities my conjecture is that taxes would not be advantageous to employ. A primary reason is that, as I have argued, there would usually be many variables that exert real influence on the expected harm but that would be left untaxed. These would typically include dimensions of care and factors describing potential victims' exposure to risk. The omission of such variables from the tax would result in inaccuracy and serious inefficiencies - some parties would do too little to reduce harm and others too much. Further, the omission of variables relevant to the expected harm would lead to excessive risk because parties would have no tax-related reason to choose these variables to reduce expected harm; and this I have suggested would be an especial problem with variables relating to care. The other important reason for my conjecture that taxes would not perform well concerns administrative costs. On one hand, the administrative costs that would actually be incurred in measuring taxed variables and collecting taxes would often be high owing to the sheer number of instances in which parties engage in potentially harmful activities. On the other, administrative costs are the latent cause of the problems stemming from the existence of untaxed

\footnotetext{
${ }^{19}$ Localized pollution might not be well-controlled by a tax. What I am about to say in the next paragraph about non-polluting activities also describes localized pollution in many respects.
} 
variables, for it is the need to avoid high administrative costs that explains why there would be untaxed variables were corrective taxes employed for most harmful activities.

\section{Strict Liability versus the Corrective Tax}

By strict liability, I refer as noted to the legal rule that allows victims of accidents to collect from injurers an amount equal to the harm that they suffered. ${ }^{20}$ Strict liability is thus different from the corrective tax in that under strict liability, the injuring party pays for the harm that turns out to occur, not for the expected harm before harm eventuates. Under strict liability a polluter would pay for the disease and property damage that pollution actually causes rather than a tax based on an estimate of such harm; and a crane operator would pay victims for the harms that crane accidents actually cause rather than a tax based on the expected harm that crane accidents would bring about; and so forth.

The argument regarding the efficiency of strict liability is similar to that regarding the efficiency of the corrective tax. Namely, if a potential injurer faces a choice about any dimension of his behavior, he will make this choice taking into account its influence on expected harm, because he will have to pay for the actual harm.

Let me now compare strict liability to the corrective tax and ask whether, or to what extent, strict liability suffers from the problems that I mentioned in regard to the tax. The first problem afflicting the tax concerned its inaccuracy. As I emphasized, for the

\footnotetext{
${ }^{20}$ In fact, strict liability may be accompanied by the defense of contributory negligence, according to which the injurer would not have to pay a victim who negligently exposed himself to danger. See, for example, Dobbs (2000, pp. 962-63). This feature of strict liability can induce victims to take desirable precautions; see Brown (1972). For simplicity, however, I abstract from the issue of victim behavior in this article.
} 
tax to equal the expected harm, the state would need to measure all the variables that influence the expected harm, but the state would be unlikely to be able to do this.

In contrast, accuracy of incentives should be good under strict liability. Under strict liability, an injurer will automatically face expected sanctions equal to expected harm as long as the injurer is held liable whenever he causes harm and the state accurately measures the extent of harm. A crane operator will face expected sanctions equal to the expected harm arising from crane accidents as long as victims of crane accidents sue and collect damages for the harms they sustain; unlike under the tax, there will be no need for the state to keep track of the usage of cranes, their type, the exposure of potential victims to risk. Likewise, a person who leaves snow and ice on the sidewalk will face expected sanctions equal to the expected harm as long as those who slip and fall bring suit and collect for harm done; there will be no need for the state to measure the amount of snow and ice left on the sidewalk, how long it takes to melt, whether it was salted, and so forth.

The second problem for the tax was that variables excluded from the tax, and notably dimensions of care, would not be controlled by it, resulting in excessive risk. This is not a problem under strict liability because it induces actors to choose all their actions so as to optimally reduce expected harm. Under strict liability, a crane operator will be induced to maneuver his crane with proper caution and not to lift unduly heavy loads even though he would not do so under a tax if care in crane use and the weight of loads were untaxed variables; and a person will be led to salt ice if that is desirable, even though he would not do that under a tax if such actions did not affect the tax determination. 
The third factor creating a problem for the tax concerned administrative cost. In this regard too, strict liability appears to enjoy a basic advantage relative to the tax. One reason is that the state need not ascertain the functional relationship between observed variables and expected harm; it need only measure the harm that eventuates.

Another reason is that liability applies only if harm arises, so that administrative costs (litigants' legal costs and the costs of operating the judicial system) are incurred only with a probability, whereas the tax applies whenever a party engages in an activity, so that administrative costs are borne with certainty. When the likelihood of harm is small, which is the case in many contexts, like operating a crane or driving, that the bearing of administrative costs occurs only when harm eventuates can be a significant advantage of liability over the tax.

The comparison of administrative costs also depends, of course, on the relative magnitudes of these costs conditional on the application of strict liability and of the tax. Under liability the fact of harm and its extent need to be established, and under the tax the levels of taxed variables need to be ascertained. Either of these tasks could be the more expensive. If the liability task is the more expensive, ${ }^{21}$ the probability-related advantage of liability would be reduced or could be reversed, whereas if the tax task is the more expensive, the probability-related advantage of liability would be reinforced.

Now let me turn to three factors that present problems for liability, because they all lower expected liability payments to below the expected harm. One such factor is difficulty in attributing harm to the party who caused it, for example, harm from pollution to the generator of pollution. If the connection between the harm and the party who

\footnotetext{
${ }^{21}$ In considering the administrative costs of applying strict liability (and, below, the negligence rule), it should be kept in mind that the great majority of cases settle, substantially reducing administrative costs.
} 
caused it cannot be established, a successful suit cannot be brought, reducing the expected liability of the party. Another factor is that the magnitude of the harm may be below the cost of suit. If this is so, there will be no financial incentive to bring suit, decreasing the expected liability of parties who might cause harms of low magnitude. An additional factor is the judgment proof problem, namely, that the party who caused harm might not have assets sufficient to pay fully for it. This could reduce the victim's incentive to bring suit, and in any event would mean that the amount paid would be less than the harm. Hence, the judgment proof problem can diminish the expected liability of injuring parties both by reducing the likelihood of suit and the magnitude of payments if suit is brought.

The foregoing factors that dilute expected liability would not affect the functioning of the tax, with one possible and partial exception. It is clear that inability to identify who was the cause of harm would not affect the functioning of the tax, as the tax is premised on an estimate of expected harm. It is also evident that the possibility that harm might be too low in magnitude to stimulate suit is not of relevance to the functioning of the tax. However, the judgment proof problem could mean that an injurer would not be able to pay the tax in full. Yet this is less likely to be the case for the tax than for the liability payment, for the tax is based on expected harm, and thus would often be lower than the actual harm. Hence, the judgment proof problem is less relevant for the tax than for liability. ${ }^{22}$

\footnotetext{
${ }^{22}$ To be clear, let me show that the tax that a person pays will exceed his expected liability, assuming that the harm $h$ that he might cause could exceed his assets $a$. Let $h$ be continuously distributed between 0 and some maximum $m$, where $0<a<m$. The tax $t$ that the person pays is $\min (a, \mathrm{E}(h))$. The liability payment that the person makes is $\min (a, h)$, so his expected liability is $\mathrm{E}(l)=\mathrm{E}(\min (a, h))<\mathrm{E}(h)$. If $\mathrm{E}(h) \leq a$, then $t=\mathrm{E}(h)>\mathrm{E}(l)$. On the other hand, if $\mathrm{E}(h)>a$, then $t=a>\mathrm{E}(\min (a, h))=\mathrm{E}(l)$. (Note that $a>\mathrm{E}(\min (a, h))$ holds since $\min (a, h)<a$ for $h<a$.) Therefore, $\mathrm{E}(l)<t$.
} 
In the light of the first three factors suggesting that strict liability has an advantage over taxation and the factors just discussed suggesting the opposite, I can add to the conjectures made at the end of the previous section about the desirability of taxes for the control of general pollution and their undesirability for the control of most other harmful activities.

I said before that taxes would be expected to work reasonably well for general pollution. It now also appears that liability would not be likely to function desirably in this context, especially because of the difficulty in attributing harm to its source. Because general pollution is the result of discharges from many different sources, it would typically be impractical or impossible to attribute particular harms to particular polluters. Moreover, difficulties in establishing causation would sometimes be compounded by the possibility that factors apart from pollution interact with it in the generation of harm. Additionally, the problem that the magnitude of harm may be too low to make suit worthwhile could sometimes be relevant. Consider, for example, premature peeling of paint or minor eye irritation. Furthermore, the judgment proof problem could apply because pollution can harm a great number of individuals or a large area of land. The joint effect of these factors would often substantially dilute expected liability for polluters and thus reinforce the attractiveness of taxes for the control of general pollution.

I also argued in the previous section that taxes would not be likely to perform well for most harmful activities, exemplified by crane accidents, automobile accidents, and slips and falls on ice and snow, because the expected harm ordinarily depends on a multiplicity of variables that would not be incorporated into the tax. Hence, the tax would be inaccurate and would also lead to excessive risk. In this section I explained 
why, under strict liability, expected liability and incentives would tend to be accurate and to induce desirable behavior, as long as suit is brought and damages are paid for the harm that actually occurs. It is also true that liability may be administratively cheaper to employ than the tax for most activities causing accidental harms, because these activities tend to cause harm only with a small probability. Hence, the tax seems significantly inferior to strict liability as an instrument for control of most harmful activities.

\section{Liability Based on the Negligence Rule versus the Corrective Tax}

Under the negligence rule a party who causes harm is obligated to pay for it only if his level of care was found to be subpar, such as failing to monitor a tank holding a pollutant for leaks, inadequately securing an object to a crane, or driving a car at excessive speed. ${ }^{23}$

The well-known economic argument supporting the negligence rule is that the rule can induce parties to exercise optimal levels of care. Suppose that the duty of care that the court requires to escape a finding of negligence is the optimal level of care. Then it will be in the interest of a party to be non-negligent and to take the optimal level of care. For example, suppose that attaching a heavy object to a crane with two sets of chains is optimal, because it is relatively inexpensive to do so and that this would eliminate a real possibility of a harmful accident. Then a rational crane operator would be motivated by the threat of liability under the negligence rule to use two sets of chains. $^{24}$

\footnotetext{
${ }^{23}$ On the definition and use of the negligence rule, see, for example, Dobbs (2000, pp. 257-73).

${ }^{24}$ See originally Brown (1972).
} 
This optimality property of the negligence rule is recognized to be limited, however, because the rule does not induce parties to choose their levels of activity efficiently. Under the negligence rule, the court does not make a judgment about a party's level of activity, only about the party's level of care. In a crane accident in which an object falls from a crane and injures an individual, a negligence inquiry would not involve a consideration of how many times the crane was used; the inquiry would concern only whether the object was properly secured, whether adequate warning of hazards was given to passersby, and the like. Because the level of activity is not addressed by the negligence rule, the level of activity will tend to be socially excessive; cranes will be used too intensively. Although parties will exercise optimal care, they will not have to pay for the harm that their activities still cause and will engage in them at too high a level. ${ }^{25}$

Now let me compare the negligence rule to the corrective tax. One consideration is the level of care. The negligence rule desirably controls levels of care, but the tax would not include these variables and would fail to control them, resulting in excessive risk. A second consideration is the level of activity. The tax efficiently controls levels of activity, whereas levels of activity tend to be excessive under the negligence rule, as I just explained.

A third issue is administrative costs. Here the negligence rule enjoys the basic advantage that I discussed in regard to strict liability, namely, that the expenses associated with the application of liability are not incurred unless harm actually

\footnotetext{
${ }^{25}$ This problem with the negligence rule was initially developed in Shavell (1980).
} 
eventuates. ${ }^{26}$ Moreover, this advantage could be greater than under strict liability, for under the negligence rule, a victim will not pursue a case unless he has reason to believe the injurer was negligent. On the other hand, if there is litigation, it will tend to be more expensive than under strict liability, because the issue of fault will need to be resolved.

A final consideration is the set of factors that reduce expected liability payments to below the expected harm - inability to trace harm to its source, losses that are less than the cost of suit, and the judgment proof problem. As was true with regard to strict liability, these factors constitute a disadvantage of the negligence rule relative to the $\operatorname{tax}^{27}$

5. The Optimal Liability Rule - Strict Liability or the Negligence Rule - versus the

\section{Corrective Tax}

In the last two sections I have compared the two major forms of liability singly to the corrective tax, but it is natural also to compare the better of the two liability rules to the corrective tax. It is clear on general grounds that the comparison of the superior liability rule to the corrective tax favors liability more than was true in the comparisons made in the previous sections. But there is a more particular reason to consider the superior liability rule.

Specifically, strict liability is likely to dominate the negligence rule when the problem of controlling injurers' levels of activity adequately is significant. As explained,

\footnotetext{
${ }^{26}$ The administrative cost advantage of the negligence rule explains why it may be socially worthwhile to employ that rule but not socially worthwhile to incorporate levels of care into the tax.

${ }^{27}$ However, these problems dilute incentives less under the negligence rule than under strict liability. See Shavell (1987, pp. 167-68).
} 
an injurer has no incentive to moderate his level of activity under the negligence rule but does under strict liability. This advantage of strict liability will tend to be substantial for activities that generate a large expected harm despite the exercise of optimal care, and there is some evidence that strict liability is in fact often employed when that is so. ${ }^{28}$

The implication of the foregoing point is to reinforce the view that liability is superior to taxation for most harmful activities. I said in the previous section that a drawback of the negligence rule in comparison to the corrective tax is that the negligence rule does not control the level of activity, whereas the corrective tax does. However, this problem of liability relative to the tax is implicitly addressed if the form of liability changes to strict liability when the social need to address injurers' levels of activity is significant.

\section{Joint Use of Corrective Taxes and Liability}

Although I have been considering corrective taxes and liability as alternative means of controlling harmful activities, they could in principle be employed jointly. In this regard, two points should be noted.

First, there is a general advantage to joint use of corrective taxes and liability, because each of these policies can sometimes compensate for problems of the other. For example, liability is unlikely to adequately address the harms that dogs cause because many of these harms - consider barking, soiling the environment, and chewing up gardens - would usually be too modest to make suit worthwhile and might also be difficult to attribute to the particular dogs that caused them. Hence, a tax on dog

\footnotetext{
${ }^{28}$ See Shavell (1980); and see also Landes and Posner (1987, p. 70) and Shavell (1987, pp. 30-32).
} 
ownership might ameliorate inadequate incentives under liability to reduce many dogrelated harms. At the same time, a tax on dog ownership would not induce dog owners to take care to prevent dog bites - by leashing dogs, keeping them away from small children, and the like - because as I articulated above, a tax would not depend on care. The use of liability, however, could well lead dog owners to take precautions to lower the risk of dog bites. Hence, we can see that joint use of taxes and liability could be desirable. $^{29}$

Second, however, there is a danger of double-billing for harm that arises if both corrective taxes and liability are imposed. If parties have to pay for more than the harms for which they are responsible, they could be induced to take wasteful precautions or be discouraged from engaging in socially desirable activities. If a firm were subject to a pollution tax for expected harm and were also strictly liable for actual harm, it would in effect be paying for twice the harm it caused.

This problem of excessive payments under a regime with both taxes and liability would be less serious under the negligence rule than under strict liability. Indeed, if the negligence rule functioned flawlessly, parties would always choose to act in a nonnegligent way and would never be found liable. Therefore, the problem of excessive payments would not arise. But uncertainties and imperfections in the negligence determination lead to findings of negligence, so that parties who cause harm bear positive expected liability under the negligence rule. Hence, the problem of excessive payments would exist under that rule even though it would not be as significant as under strict liability.

${ }^{29}$ In Shavell (2011) I show that under fairly general assumptions joint use of taxes and strict liability is desirable, and that, as I am about to explain in the text, the tax should be less than the expected harm. 
The problem of excessive payments under a tax and liability regime seemingly could be alleviated by reducing the amount of the tax to below the expected harm and by letting expected liability take up the slack in payments, but attention would have to be paid to how such a policy is implemented.

\section{Conclusion}

I have compared the corrective tax to liability as solutions to the problem of controlling socially harmful activities and have attempted to articulate the advantages of each policy in theory. In light of this inquiry, I concluded that liability should on the whole be superior to the corrective tax in governing most harmful activities, a view that is in accord with the observed predominance of liability over taxation. ${ }^{30}$ My judgments about the relative virtues of liability over taxation were based mainly on the impracticality of employing taxes that properly reflect the usually numerous variables that significantly affect expected harm, on the fact that the state need only measure the harm under strict liability to create desirable incentives, on the fact that the negligence rule generates desirable incentives to control dimensions of care whereas the tax does not, and on administrative cost advantages of liability deriving from its being applied only when harm occurs.

I also suggested that the tax should be superior to liability as a means of controlling general pollution. This view was premised on the assumption that the tax

\footnotetext{
${ }^{30}$ Another explanation for the limited use of taxes is political: that they are unpopular because they oblige governed parties to make payments. See, for example, Revesz and Stavins (2007, pp. 558-61), who discuss this explanation for the lack of use of taxation in the control of pollution and the appeal of regulation as an alternative. Negligence-based liability would seem to hold political attractions similar to those of regulation, for under the negligence rule as under regulation, parties engaged in harmful activities do not have to make payments if they adhere to the requirements set out by the state. Strict liability, however, should be politically unpopular for the reason that taxes are said to be.
} 
would perform well because only a single variable, the quantity of emissions, largely determines expected harm, and on the assumption that incentives under liability would be significantly diluted by the inability of victims to attribute harm to injurers and to related problems in bringing suit. 


\section{References}

Adar, Zvi, and James M. Griffin. 1976. Uncertainty and the Choice of Pollution Control Instruments. Journal of Environmental Economics and Management. 3:178-188.

Baumol, William J., and Wallace E. Oates. 1988. The Theory of Environmental Policy. New York: Cambridge University Press.

Bovenberg, A. Lans, and Lawrence H. Goulder. 2002. Environmental Taxation and Regulation. Ch. 23, pp. 1471-1545, in Handbook of Public Economics, vol. 3, Alan J. Auerbach and Martin Feldstein, editors. Amsterdam: Elsevier.

Brown, John. 1973. Toward an Economic Theory of Liability. Journal of Legal Studies. 2:323-350.

Coase, Ronald. 1960. The Problem of Social Cost. Journal of Law and Economics. $3: 1-44$.

Dobbs, Dan B. 2000. The Law of Torts. St. Paul: West.

Farber, Daniel A., Jody Freeman, Ann E. Carlson, and Roger W. Findlay. 2006. Cases and Materials on Environmental Law, seventh ed. St. Paul: West.

Helfand, Gloria E., Peter Berck, and Tim Maull. The Theory of Pollution Policy. Ch. 6, pp. 249-303, in Handbook of Environmental Economics, vol. 1, Karl-Göran Mäler and Jeffrey R. Vincent, editors. Amsterdam: Elsevier.

Kaplow, Louis, and Steven Shavell. 2002. On the Superiority of Corrective Taxes to Quantity Regulation. American Law and Economics Review. 4:1-17.

Landes, William M., and Richard A. Posner. 1987. The Economic Structure of Tort Law. Cambridge: Harvard University Press.

Mankiw, N. Gregory. 2009. Principles of Microeconomics, Fifth edition. Mason, Ohio: South-Western Cengage Learning.

Mas-Colell, Andreu, Michael D. Whinston, and Jerry R. Green. 1995. Microeconomic Theory. New York: Oxford University Press.

Pigou, A. C. 1932. The Economics of Welfare, Fourth edition. London: Macmillan.

Pindyck, Robert S., and Daniel L. Rubinfeld. 2009. Microeconomics, Seventh edition. Saddle River, NJ: Prentice-Hall.

Posner, Richard A. 2007. Economic Analysis of Law, Seventh edition. New York: Aspen. 
Revesz, Richard L., and Robert N. Stavins. 2007. Environmental Law. Ch. 8, pp. 499589, in Handbook of Law and Economics, vol. 1, A. Mitchell Polinsky and Steven Shavell, editors. Amsterdam: Elsevier.

Shavell, Steven. 1980. Strict Liability versus Negligence. Journal of Legal Studies. 9:1-25.

Shavell, Steven. 1987. Economic Analysis of Accident Law. Cambridge: Harvard University Press.

Shavell, Steven. 1993. The Optimal Structure of Law Enforcement. Journal of Law and Economics. 36:255-287.

Shavell, Steven. 2011. Corrective Taxation versus Liability. Amerian Economic Review. Forthcoming in the papers and proceedings May issue.

Stavins, Robert N. 2003. Experience with Market-Based Environmental Policy Instruments. Ch. 9, pp. 355-435, in Handbook of Environmental Economics, vol. 1, Karl-Göran Mäler and Jeffrey R. Vincent, editors. Amsterdam: Elsevier.

Weitzman, Martin L. 1974. Prices vs. Quantities. Review of Economic Studies. 41:477491.

White, Michelle J., and Donald Wittman. 1983. A Comparison of Taxes, Regulation, and Liability Rules Under Imperfect Information. Journal of Legal Studies. $12: 413-425$. 